\title{
Soil nitrous oxide emissions in long-term cover crops-based rotations under subtropical climate
}

\author{
Juliana Gomes ${ }^{a}$, Cimélio Bayer ${ }^{\mathrm{a}, *}$, Falberni de Souza Costa ${ }^{\mathrm{b}}$, Marisa de Cássia Piccolo ${ }^{\mathrm{c}}$, \\ Josiléia Acordi Zanatta ${ }^{\mathrm{d}}$, Frederico Costa Beber Vieira ${ }^{\mathrm{e}}$, Johan Six ${ }^{\mathrm{f}}$ \\ ${ }^{a}$ Departamento de Solos, Universidade Federal do Rio Grande do Sul, P.O. Box 15100, 91540-000 Porto Alegre, RS, Brazil \\ ${ }^{\mathrm{b}}$ Empresa Brasileira de Pesquisa Agropecuária, P.O. Box 321, 69908-970 Rio Branco, AC, Brazil

 \\ dempresa Brasileira de Pesquisa Agropecuária, P.O. Box 661, 79804-970 Dourados, MS, Brazil \\ ${ }^{\text {e }}$ Departamento de Solos, Universidade Federal do Pampa, 973000-000 São Gabriel, RS, Brazil \\ ${ }^{\mathrm{f}}$ Department of Plant Sciences, University of California, 95616 Davis, CA, USA
}

\section{A R T I C L E I N F O}

\section{Article history:}

Received 6 February 2009

Received in revised form 18 September 2009

Accepted 3 October 2009

\section{Keywords:}

Soil management

No-till

Legumes

Global warming

Mineral N

\begin{abstract}
A B S T R A C T
It has been shown that cover crops can enhance soil nitrous oxide $\left(\mathrm{N}_{2} \mathrm{O}\right)$ emissions, but the magnitude of increase depends on the quantity and quality of the crop residues. Therefore, this study aimed to evaluate the effect of long-term (19 and 21 years) no-till maize crop rotations including grass [black oat (Avena strigosa Schreb)] and legume cover crops [vetch (Vigna sativa L.), cowpea (Vigna unguiculata L. Walp), pigeon pea (Cajanus cajan L. Millsp.) and lablab (Dolichos lablab)] on annual soil $\mathrm{N}_{2} \mathrm{O}$ emissions in a subtropical Acrisol in Southern Brazil. Greater soil $\mathrm{N}_{2} \mathrm{O}$ emissions were observed in the first 45 days after the cover crop residue management in all crop rotations, varying from $-20.2 \pm 1.9$ to $163.9 \pm 24.3 \mu \mathrm{g} \mathrm{N} \mathrm{m}^{-2} \mathrm{~h}^{-1}$. Legumebased crop rotations had the largest cumulative emissions in this period, which were directly related to the quantity of $\mathrm{N}\left(r^{2}=0.60, p=0.13\right)$ and inversely related to the lignin: $\mathrm{N}$ ratio $\left(r^{2}=0.89, p=0.01\right)$ of the cover crop residues. After this period, the mean fluxes were smaller and were closely related to the total soil $\mathrm{N}$ stocks $\left(r^{2}=0.96, p=0.002\right)$. The annual soil $\mathrm{N}_{2} \mathrm{O}$ emission represented $0.39-0.75 \%$ of the total $\mathrm{N}$ added by the legume cover crops. Management-controlled soil variables such as mineral $\mathrm{N}\left(\mathrm{NO}_{3}{ }^{-}\right.$and $\left.\mathrm{NH}_{4}{ }^{+}\right)$and dissolved organic $\mathrm{C}$ influenced more the $\mathrm{N}_{2} \mathrm{O}$ fluxes than environmental-related variables as water-filled pore space and air and soil temperature. Consequently, the synchronization between $\mathrm{N}$ mineralization and $\mathrm{N}$ uptake by plants seems to be the main challenge to reduce $\mathrm{N}_{2} \mathrm{O}$ emissions while maintaining the environmental and agronomic services provided by legume cover crops in agricultural systems.
\end{abstract}

(c) 2009 Elsevier B.V. All rights reserved.

\section{Introduction}

Nitrous oxide $\left(\mathrm{N}_{2} \mathrm{O}\right)$ is a major greenhouse gas (GHG). Although emissions of $\mathrm{N}_{2} \mathrm{O}$ are numerically smaller than those for the other GHGs, they are a major contributor (about 15\%) to the current increase in global warming (Isermann, 1994), mostly because the global warming potential (GWP) of $\mathrm{N}_{2} \mathrm{O}$ is about 296 times higher than that from carbon dioxide $\left(\mathrm{CO}_{2}\right)$. Arable soils are responsible for about $57 \%$ of the annual $\mathrm{N}_{2} \mathrm{O}$ emissions in the world (Mosier et al., 1998). In Brazil, agriculture contributes about $94 \%$ to the total $\mathrm{N}_{2} \mathrm{O}$ emissions (EMBRAPA, 2006). According to estimations based on the emission factors currently assumed by the Inter-

\footnotetext{
* Corresponding author. Tel.: +55 51 33086017; fax: +55 5133086050 E-mail address: cimelio.bayer@ufrgs.br (C. Bayer).
}

governmental Panel on Climate Change (IPCC), $478 \mathrm{Gg} \mathrm{N}_{2} \mathrm{O}$ are annually emitted from arable soils in Brazil.

In Southern Brazil, approximately $43 \%$ of total $\mathrm{N}_{2} \mathrm{O}$ emissions $(107 \mathrm{Gg}$ ) come from agricultural soils and constitute the greatest single source of $\mathrm{N}_{2} \mathrm{O}$ to the atmosphere (EMBRAPA, 2006). However, most GHG studies have been conducted in the North Amazonia region (Neill et al., 2005; Carmo et al., 2007), while only few studies have attempted to evaluate the influence of different soil management practices on $\mathrm{N}_{2} \mathrm{O}$ emissions and to identify the main soil and environmental driving factors determining $\mathrm{N}_{2} \mathrm{O}$ emissions in subtropical agricultural systems of Southern Brazil (Pavei, 2005; Giacomini et al., 2006; Jantalia et al., 2008). In Southern Brazil, 8 Mha are cultivated with annual crops and the use of cover crops-based cropping systems has substantially increased in the last years as a consequence of the adoption of conservation practices, mainly no-tillage (Mielniczuk et al., 2003). 
Often, short-term peaks in $\mathrm{N}_{2} \mathrm{O}$ emissions have been observed after crop residues are returned to the soil (Baggs et al., 2000; Millar et al., 2004). The magnitude of the emissions, however, is dependent on the chemical composition (Millar and Baggs, 2004; Garcia-Ruiz and Baggs, 2007), and the quantity of plant residues added to the soil (Aulakh et al., 2001). The contents of $\mathrm{N}$ and lignin in the plant residues are important variables determining the $\mathrm{N}$ mineralization kinetics in the soil (Constantinides and Fownes, 1994) and thus can also affect soil $\mathrm{N}_{2} \mathrm{O}$ emissions. Soil $\mathrm{N}_{2} \mathrm{O}$ emissions tend to be greater when the added crop residues have a low C:N ratio (Huang et al., 2004), as well as a low lignin:N ratio (Millar and Baggs, 2004). In this context, the addition of legume cover crop residues-residues characterized by a high $\mathrm{N}$ concentration and a low $\mathrm{C}: \mathrm{N}$ ratio-to the soil is expected to increase $\mathrm{N}_{2} \mathrm{O}$ emission in comparison to emissions observed in grass-based cropping systems (Baggs et al., 2001). Garcia-Ruiz and Baggs (2007) have reported $\mathrm{N}_{2} \mathrm{O}$ emissions up to three times higher in a soil with a legume residue input than in a non-amended soil. However, the magnitude of response to legume residue addition is expected to be dependent on environmental and soil conditions (Rochette et al., 2004). Namely soil $\mathrm{N}_{2} \mathrm{O}$ emissions are affected by water content, soil temperature, and soil compaction (Ball et al., 1999) due to their impact on oxygen supply and substrate availability (labile organic C and mineral N) (Beauchamp, 1997). The complexity of interactions among these driving factors controlling soil $\mathrm{N}_{2} \mathrm{O}$ emissions has been largely reported (Kaiser et al., 1998; Baggs et al., 2003). However, few studies have assessed these interactions under subtropical climatic conditions of Southern Brazil (Jantalia et al., 2008).

This study aimed to evaluate the long-term ( $>19$ years) effect of no-till cover crop based rotations on the annual soil $\mathrm{N}_{2} \mathrm{O}$ emissions from a subtropical Acrisol in Southern Brazil, as well as to identify environmental and soil factors controlling soil $\mathrm{N}_{2} \mathrm{O}$ emissions in these systems.

\section{Material and methods}

\subsection{Local climate and soil characteristics}

Soil $\mathrm{N}_{2} \mathrm{O}$ emissions were evaluated in two long-term field experiments (19 and 21 years) established at the Agronomic Experimental Station of the Federal University of Rio Grande do Sul, located in Eldorado do Sul county $\left(30^{\circ} 06^{\prime} \mathrm{S}, 51^{\circ} 41^{\prime} \mathrm{W}\right.$; about $45 \mathrm{~m}$ altitude), in Rio Grande do Sul State, Southern Brazil. The local climate is subtropical humid (Cfa type according to Köppen classification), with a mean annual temperature of $19.4{ }^{\circ} \mathrm{C}$ and a mean annual rainfall of $1440 \mathrm{~mm}$. The soil is classified as an Alumic Acrisol by the FAO classification system and as a Typic Paleudult by the USA classification system. Soil particle size distribution is $540 \mathrm{~g}$ sand $\mathrm{kg}^{-1}$ soil, $240 \mathrm{~g}$ silt $\mathrm{kg}^{-1}$ soil, and $220 \mathrm{~g}$ clay $\mathrm{kg}^{-1}$ soil, with the clay fraction dominated by kaolinite $\left(720 \mathrm{~g} \mathrm{~kg}^{-1}\right)$ and iron oxides (109 $\mathrm{g} \mathrm{kg}^{-1}$ of $\mathrm{Fe}_{2} \mathrm{O}_{3}$ ).

\subsection{Long-term experiments}

Two experiments were adjacently established in 1983 and 1985 , both in a randomized block design and with three replicates. At that time, the soil showed visible signs of physical degradation (e.g. like rill erosion, low water infiltration, and compaction) caused by conventional ploughing and disking implemented for the previous two decades. The crop rotations (winter/summer crop) selected for this study were pigeon pea (Cajanus cajan $\mathrm{L}$. Millsp) + maize (Zea mays L.) (P + M), lablab (Dolichos lablab) + maize $(\mathrm{L}+\mathrm{M})$, and black oat (Avena strigosa Schreb) + vetch (Vigna sativa $\mathrm{L}$.)/maize + cowpea (Vigna unguiculata $\mathrm{L}$. Walp) $(\mathrm{O}+\mathrm{V} / \mathrm{M}+\mathrm{C})$ from the oldest experiment (21 years), and black oat/maize $(\mathrm{O} / \mathrm{M})$ and vetch/maize $(\mathrm{V} / \mathrm{M})$ from the 19-year-old experiment. Vetch is a subtropical legume, while pigeon pea, lablab, and cowpea are tropical legume species. All crop rotations have been managed under no-till and there was no $\mathrm{N}$ fertilizer applied since the establishment of the experiments.

After the management of winter and summer cover crops by glyphosate-based herbicide and roller-cutter in October 30, 2003, a $2 \mathrm{~m} \times 2 \mathrm{~m}$ area was delimited in one plot of each treatment, where two aluminum-made bases for gas sampling were placed. Shoot residues of the cover crops were uniformly distributed across the surface of the soil, at amounts equivalent to 5 and $4 \mathrm{Mg} \mathrm{ha}^{-1}$ of dry matter (DM) for the single oat and vetch, respectively, and a mix of 4:2.5 Mg DM ha ${ }^{-1}$ (oat:vetch) for the $\mathrm{O}+\mathrm{V} / \mathrm{M}+\mathrm{C}$ crop rotation (Table 1). For pigeon pea, cowpea and lablab, historical shoot biomass production of 12.6, 3.2 and 7.7 $\mathrm{Mg} \mathrm{DM} \mathrm{ha}^{-1}$, respectively, were assumed. In the $2 \mathrm{~m} \times 2 \mathrm{~m}$ area, spontaneous weeds were managed with glyphosate when necessary. In April 2005, after the maize grain harvest, shoot residues of maize were uniformly distributed across the soil surface in amounts equivalent to the DM input measured in each respective treatment (Table 1).

\subsection{Air sampling and $\mathrm{N}_{2} \mathrm{O}$ analysis}

The sampling for soil $\mathrm{N}_{2} \mathrm{O}$ emission analysis was performed for about a year, with weekly sampling in the post-management period that corresponded to the first 45 days after cover crop management (seven sampling events in this period). In the following period, sampling had intervals from 15 to 60 days (seven sampling events). The sampling schedule is shown in Fig. 1.

Air samples were manually taken from closed flux chambers ( $0.25 \mathrm{~m}$ diameter $\times 0.2 \mathrm{~m}$ height) per treatment composed of a PVC-cylinder with the top border hermetically closed. At the time of the gas measurements this chamber was fitted on to an aluminum base $\left(0.0346 \mathrm{~m}^{2}\right)$ inserted $5 \mathrm{~cm}$ into the soil. The aluminum base was equipped at the top with a circular water channel (diameter of 0.21 and $0.28 \mathrm{~m}$ of inner and outer ring, respectively, and height of $0.05 \mathrm{~m}$ ) to ensure a good seal between the base and the PVC chamber. The aluminum bases were only

Table 1

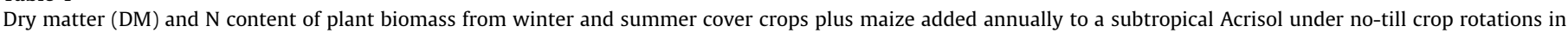
Southern Brazil.

\begin{tabular}{|c|c|c|c|c|c|c|}
\hline \multirow[t]{3}{*}{ Crop rotation $^{\mathrm{a}}$} & \multirow{2}{*}{\multicolumn{2}{|c|}{$\begin{array}{l}\text { Winter } \\
\text { Cover crops }\end{array}$}} & \multicolumn{4}{|l|}{ Summer } \\
\hline & & & \multicolumn{2}{|l|}{ Cover crops } & \multicolumn{2}{|l|}{ Maize } \\
\hline & $\mathrm{DM}\left(\mathrm{Mg} \mathrm{ha}^{-1}\right)$ & $\mathrm{N}\left(\mathrm{kg} \mathrm{ha}^{-1}\right)$ & $\mathrm{DM}\left(\mathrm{Mg} \mathrm{ha}^{-1}\right)$ & $\mathrm{N}\left(\mathrm{kg} \mathrm{ha}^{-1}\right)$ & $\mathrm{DM}\left(\mathrm{Mg} \mathrm{ha}^{-1}\right)$ & $\mathrm{N}\left(\mathrm{kg} \mathrm{ha}^{-1}\right)$ \\
\hline $\mathrm{O} / \mathrm{M}$ & 5.0 & 61 & - & - & 6.2 & 37.3 \\
\hline $\mathrm{V} / \mathrm{M}$ & 4.0 & 115 & - & - & 8.4 & 29.8 \\
\hline $\mathrm{O}+\mathrm{V} / \mathrm{M}+\mathrm{C}$ & 6.5 & 121 & 3.2 & 76 & 8.5 & 34.7 \\
\hline$P+M^{b}$ & - & - & 12.6 & 327 & 7.0 & 40.6 \\
\hline$L+M^{b}$ & - & - & 7.7 & 128 & 8.0 & 39.5 \\
\hline
\end{tabular}

a $\mathrm{O}$, oat; V, vetch; C, cowpea; P, pigeon pea; L, lab-lab; M, maize.

b Dry matter and $\mathrm{N}$ and $\mathrm{C}$ additions estimated from historical data of the experiment. 


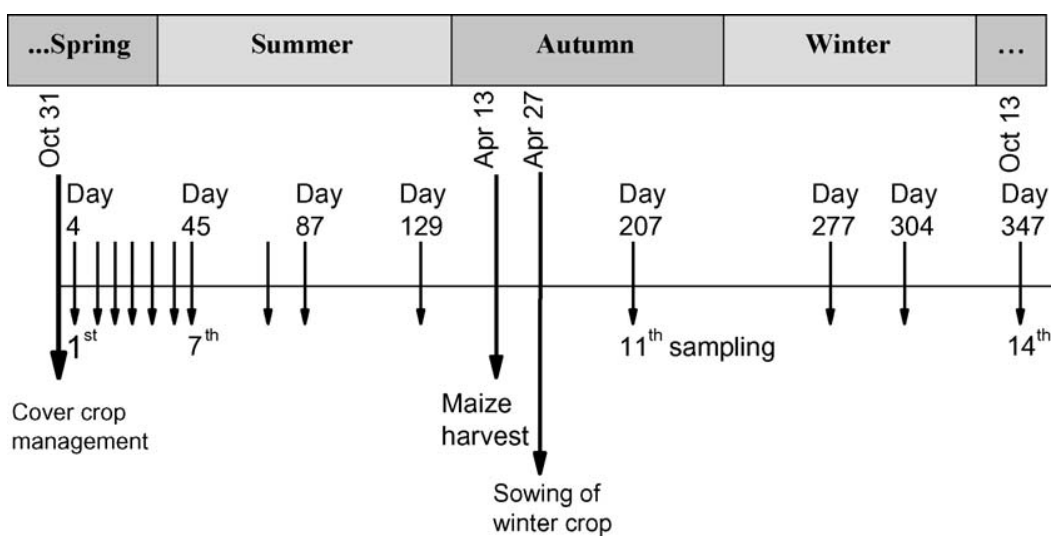

Fig. 1. Schedule of air sampling and agricultural practices across the seasons.

removed from the field at the time of sowing and harvest. The chambers had a thermometer with outside display for monitoring the temperature of the inside the chamber, and an internal fan for homogenizing the chamber atmosphere before sampling. In the top, the chambers were equipped with a rubber septum to take air samples.

Air samples were taken simultaneously in the treatments, beginning at 9 a.m. and taking samples at $0,15,30$, and $45 \mathrm{~min}$ after closing the chamber. The syringes (polypropylene, $20 \mathrm{~mL}$ ) were immediately disposed in a cooler box, where they were kept at low temperature, and dispatched by express mail to the lab (i.e., the Environmental Biogeochemical Lab, Nuclear Energy Centre, University of Sao Paulo) for analysis of $\mathrm{N}_{2} \mathrm{O}$ concentrations by gas chromatography (GC-Shimadzu 14A); samples were analyzed within $24 \mathrm{~h}$ of the sampling. The chromatograph was equipped with Porapak-Q column set at $30^{\circ} \mathrm{C}$ temperature, $\mathrm{N}_{2}$ as carrier gas in flow of $30 \mathrm{~mL} \mathrm{~min}{ }^{-1}$, injector temperature was $50{ }^{\circ} \mathrm{C}$, and $\mathrm{ECD}$ detector was at a temperature of $320^{\circ} \mathrm{C}$.

Gas molar volume $\left(V_{\mathrm{m}}\right)$ was corrected for headspace chamber air temperature measured at the sampling time, and the $\mathrm{N}_{2} \mathrm{O}$ fluxes $(f)$ were calculated taking into account the change in $\mathrm{N}_{2} \mathrm{O}$ concentration in the chamber during the chamber closure time $(\Delta C / \Delta t)$, the volume of the chamber $\left(V, 0.00982 \mathrm{~m}^{3}\right)$, the area of the soil covered by the chamber $\left(A, 0.0346 \mathrm{~m}^{2}\right)$, and the molecular weight of $\mathrm{N}_{2} \mathrm{O}(\mathrm{m})$, according to the following equation (Jantalia et al., 2008):

$f=\frac{\Delta C}{\Delta t} \times \frac{V}{A} \times \frac{m}{V_{m}}$

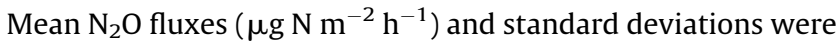
calculated from the fluxes measured in the two chambers per treatment. Daily $\mathrm{N}_{2} \mathrm{O}$ fluxes were estimated by linear interpolation assuming that the 9:00-10:00 a.m. sampling period provided a valid estimation of average daily $f_{\mathrm{N}_{2} \mathrm{O}}$. This assumption is fully supported by the results reported by Jantalia et al. (2008) working in the same region. These authors verified that air sampling at $10: 00$ a.m. resulted in $\mathrm{N}_{2} \mathrm{O}$ fluxes only $11 \%$ higher than the mean daily $\mathrm{N}_{2} \mathrm{O}$ fluxes, and air sampling in the middle of the morning was, therefore, considered the most optimal sampling time to estimate mean daily $\mathrm{N}_{2} \mathrm{O}$ flux (Jantalia et al., 2008). Cumulative fluxes for the post-management period (45 days) and for the oneyear period were calculated by integration of the daily $\mathrm{N}_{2} \mathrm{O}$ emissions.

\subsection{Soil and environment analyses}

The soil $\mathrm{N}$ stock was evaluated through a soil sampling at $0-2.5$, $2.5-7.5,7.5-17.5$, and $17.5-30.0 \mathrm{~cm}$ soil layers in October 2002, before the cover crop management, in three field replicates of each treatment. Soil sub-samples were oven-dried $\left(50{ }^{\circ} \mathrm{C}\right)$, ground, and the total $\mathrm{N}$ concentration was determined by digestion followed by Kjeldahl distillation according to procedures described by Bremner (1960). Soil N stocks $(0-30 \mathrm{~cm})$ were calculated using the equivalent soil mass approach (Ellert and Bettany, 1995), taking the soil mass from adjacent native grassland as reference. Soil bulk densities used for the equivalent soil mass calculations are reported by Zanatta et al. (2007) and Vieira et al. (2008).

The first 11 sampling events for $\mathrm{N}_{2} \mathrm{O}$ analyses were complemented by evaluations of soil gravimetric moisture, dissolved organic $\mathrm{C}$ (DOC), and $\mathrm{NO}_{3}{ }^{-}$and $\mathrm{NH}_{4}{ }^{+}$contents in composite soil samples (4 sub-samples) of 0-0.3 $\mathrm{m}$ depth, and of soil temperature at $0.05 \mathrm{~m}$ depth, within the $2 \mathrm{~m} \times 2 \mathrm{~m}$ area. The gravimetric moisture content was obtained by drying the soil at $105^{\circ} \mathrm{C}$ for $24 \mathrm{~h}$, and geo-thermometers were used to measure soil temperature. Samples for DOC analysis were air dried, ground, and sieved through a $2 \mathrm{~mm}$ sieve. The DOC was extracted by horizontally shaking a suspension of $5 \mathrm{~g}$ soil and $50 \mathrm{~mL}$ distilled water $(1: 10)$ for $10 \mathrm{~h}$. The suspension was centrifuged and the supernatant filtered through regenerated cellulose membrane filters of $0.45 \mu \mathrm{m}$ pore diameter (Chantigny, 2003). The DOC contents were determined by dry combustion using a TOC-VCSH Analyzer Shimadzu ${ }^{\circledR}$. Soil mineral $\mathrm{N}$ was extracted with $1 \mathrm{M} \mathrm{KCl}$ and determined by the Kjeldahl distillation method according to procedures described by Bremner (1960).

The water-filled pore space (\%WFPS) was calculated based on the results of gravimetric water content determined for each sampling date and the soil bulk density values reported by Vieira et al. (2008, 21-year-old exp.) and Zanatta et al. (2007, 19-year-old exp.). We assumed that the main factor affecting WFPS in this well structured no-tilled soil during the short sampling period ( 1 year) was the variation of soil water content (range of $5.8-26.1 \mathrm{~g} \mathrm{~kg}^{-1}$ ) due to rainfall events. This approach is coherent with the small temporal variation of soil bulk density verified in previous studies on these experiments. For example, soil bulk density (mean for the $0-0.3 \mathrm{~m}$ soil layer) in no-tillage soil varied from $1.58 \mathrm{~g} \mathrm{~cm}^{-3}$ in 1990 to $1.62 \mathrm{~g} \mathrm{~cm}^{-3}$ in 2001 (Zanatta et al., 2007), while the range of soil bulk density in the was $1.49-1.62 \mathrm{~g} \mathrm{~cm}^{-3}$ for the different no-till crop rotations in the 19th year of the experiment (Vieira et al., 2008).

Local data of air temperature and rainfall (Fig. 2) for the evaluated period were obtained from the Automatic Meteorological Station from the Department of Forage and Meteorology (UFRGS), located at about $1 \mathrm{~km}$ from the experimental area.

\subsection{Quality of crop residues}

Samples of cover crops were taken in their flowering stage and analyzed for total $\mathrm{C}$ and $\mathrm{N}$ contents using dry combustion (TOCVCSH Analyzer Shimadzu ${ }^{\circledR}$ ) and digestion followed by Kjeldahl 


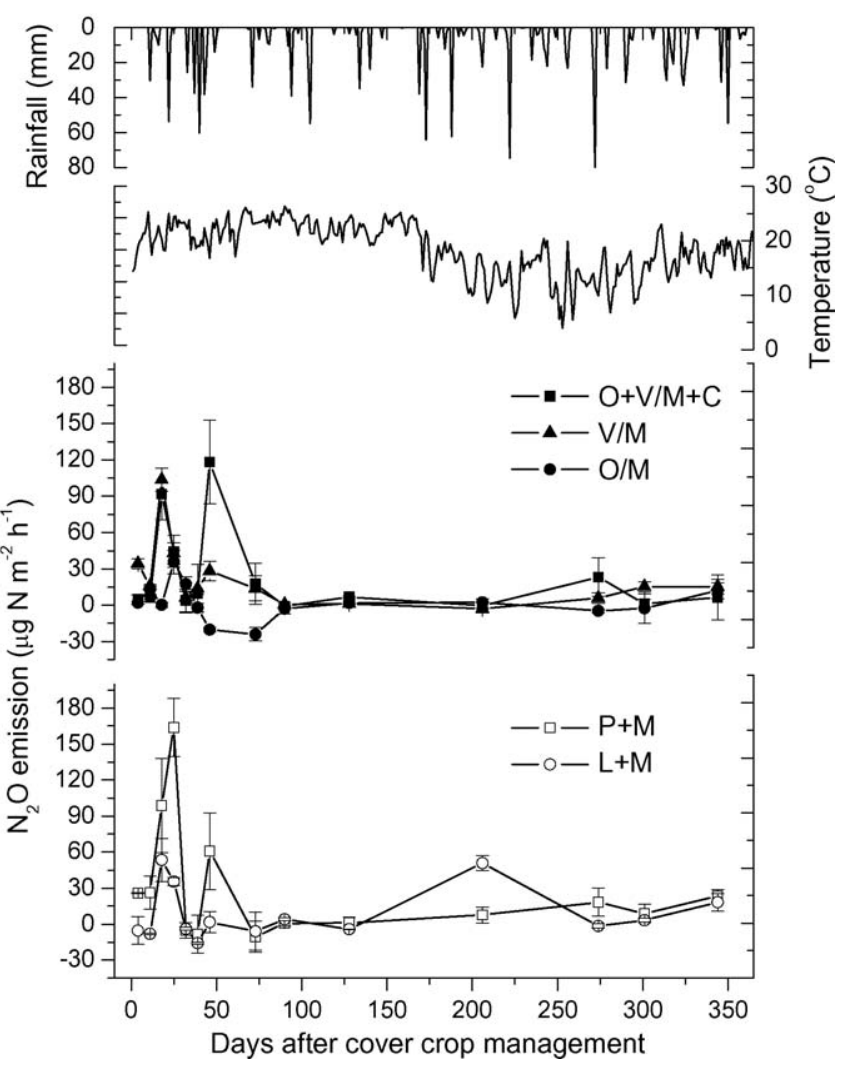

Fig. 2. Rainfall (mm), air temperature $\left({ }^{\circ} \mathrm{C}\right)$ and soil $\mathrm{N}_{2} \mathrm{O}$ emissions $\left(\mu \mathrm{g} \mathrm{N} \mathrm{m}{ }^{-2} \mathrm{~h}^{-1}\right.$ ) from an Acrisol under no-till crop rotations in Southern Brazil. O, oat; V, vetch; C, cowpea; P, pigeon pea; L, lablab; M, maize. Vertical bars represent the standard deviation $(n=2)$.

Table 2

Mean chemical composition ( \pm standard deviation, $n=3$ ) of cover crop residues added to a subtropical Acrisol under no-till crop rotations in Southern Brazil.

\begin{tabular}{lllcl}
\hline Crop & $\mathrm{N}(\%)$ & $\mathrm{C}: \mathrm{N}$ ratio $\left(\mathrm{g} \mathrm{kg}^{-1}\right)$ & Lignin $\left(\mathrm{g} \mathrm{kg}^{-1}\right)$ & Lignin: $\mathrm{N}\left(\mathrm{g} \mathrm{kg}^{-1}\right)$ \\
\hline Oat & $1.22 \pm 0.15$ & $33 \pm 3$ & $7.2 \pm 0.3$ & $5.9 \pm 0.2$ \\
Vetch & $2.88 \pm 0.22$ & $14 \pm 1$ & $9.6 \pm 0.2$ & $3.3 \pm 0.1$ \\
Oat + vetch & $1.86 \pm 0.10$ & $22 \pm 2$ & $8.3 \pm 0.2$ & $4.5 \pm 0.2$ \\
Cowpea & $2.37 \pm 0.18$ & $17 \pm 2$ & $9.8 \pm 0.3$ & $4.1 \pm 0.2$ \\
Pigeon pea & $2.59 \pm 0.19$ & $15 \pm 1$ & $6.6 \pm 0.1$ & $2.6 \pm 0.1$ \\
Lablab & $1.66 \pm 0.09$ & $24 \pm 2$ & $10.1 \pm 0.3$ & $6.1 \pm 0.2$ \\
\hline
\end{tabular}

distillation, respectively (Table 1 ). Lignin contents (Table 2) were determined by the van Soest method (van Soest and Wine, 1968). All analyses were performed in triplicate.

\subsection{Statistical analysis}

Considering that the measurements of $\mathrm{N}_{2} \mathrm{O}$ were accomplished with two chambers in the same plot and, thus, the evaluations are not based on field replicates, a non-descriptive statistical analysis was performed and the mean standard deviation values were used to discriminate the crop rotations. Relationship between variables was evaluated by means of determination coefficient $\left(r^{2}\right)$ of polynomial regressions. Results of soil $\mathrm{N}_{2} \mathrm{O}$ emissions, soil mineral $\mathrm{N}$, DOC, WFPS, soil temperature and air temperature were subjected to multivariate analysis (Principal Component Analysis, PCA) in order to evaluate the importance of each driving factor on the soil $\mathrm{N}_{2} \mathrm{O}$ emission, using the software MULTIV (Pillar, 1997). The significance of ordination axes and clusters were evaluated by using bootstrap re-sampling. Correlation coefficients $(r)$ larger than $|0.60|$ were considered for the significance between variables and ordination axes.

\section{Results}

\subsection{Soil $\mathrm{N}_{2} \mathrm{O}$ emissions}

The crop rotations had the greatest soil $\mathrm{N}_{2} \mathrm{O}$ emission in the first 45 days after management of cover crop residues (herein called postmanagement period), which ranged from $-20.2 \pm 1.9 \mu \mathrm{g} \mathrm{N} \mathrm{m}^{-2} \mathrm{~h}^{-1}$ in the $\mathrm{O} / \mathrm{M}$ to $163.9 \pm 24.3 \mu \mathrm{g} \mathrm{N} \mathrm{m}{ }^{-2} \mathrm{~h}^{-1}$ in $\mathrm{P}+\mathrm{M}$ systems (Fig. 2). The greatest soil $\mathrm{N}_{2} \mathrm{O}$ emissions were found in the legume-based crop rotations, with a mean of $31.6 \pm 3.7 \mu \mathrm{g} \mathrm{N} \mathrm{m}^{-2} \mathrm{~h}^{-1}$ for the postmanagement period, while the $\mathrm{O} / \mathrm{M}$ exhibited the lowest mean emission $\left(8.6 \pm 2.2 \mu \mathrm{g} \mathrm{N} \mathrm{m}^{-2} \mathrm{~h}^{-1}\right)$. The largest fluxes were observed at the 18th and 25th day, which coincided with the greatest contents of mineral $\mathrm{N}$ and DOC, and a WFPS larger than 70\% (Fig. 3). The V/M crop rotation had its maximum soil $\mathrm{N}_{2} \mathrm{O}$ emission earlier in the season than the other crop rotations, with $103.5 \pm 9.4 \mu \mathrm{g} \mathrm{N} \mathrm{m}{ }^{-2} \mathrm{~h}^{-1}$ at the 18 th day. On the other hand, the $\mathrm{O}+\mathrm{V} / \mathrm{M}+\mathrm{C}$ system had its greatest emission rate $\left(118.2 \pm 34.6 \mu \mathrm{g} \mathrm{N} \mathrm{m}^{-2} \mathrm{~h}^{-1}\right)$ only at the 46th day after crop residue management.

Among the legume-based crop rotations, the $\mathrm{L}+\mathrm{M}$ had the smallest soil $\mathrm{N}_{2} \mathrm{O}$ emission at all sampling events of the postmanagement period (mean of $9.2 \pm 3.2 \mu \mathrm{g} \mathrm{N} \mathrm{m}^{-2} \mathrm{~h}^{-1}$ ), while the mean emission for $\mathrm{P}+\mathrm{M}$ was about five times higher $\left(49.5 \pm 6.7 \mu \mathrm{g} \mathrm{N} \mathrm{m}^{-2} \mathrm{~h}^{-1}\right)$. Consequently, the cumulative emission for the post-management period was ranked in the following order: $\mathrm{P}+\mathrm{M} \quad\left(0.535 \pm 0.072 \mathrm{~kg} \mathrm{~N} \mathrm{ha}^{-1}\right)>\mathrm{O}+\mathrm{V} / \mathrm{M}+\mathrm{C} \quad(0.374 \pm$ $\left.0.005 \mathrm{~kg} \mathrm{~N} \mathrm{ha}^{-1}\right)>\mathrm{V} / \mathrm{M}\left(0.358 \pm 0.047 \mathrm{~kg} \mathrm{~N} \mathrm{ha}^{-1}\right)>\mathrm{L}+\mathrm{M}(0.103 \pm$ $0.035 \mathrm{~g} \mathrm{~N} \mathrm{ha}^{-1}$ ); these emissions were equivalent to $43 \%, 29 \%, 44 \%$, and $9 \%$ of the cumulative annual emissions, respectively. The

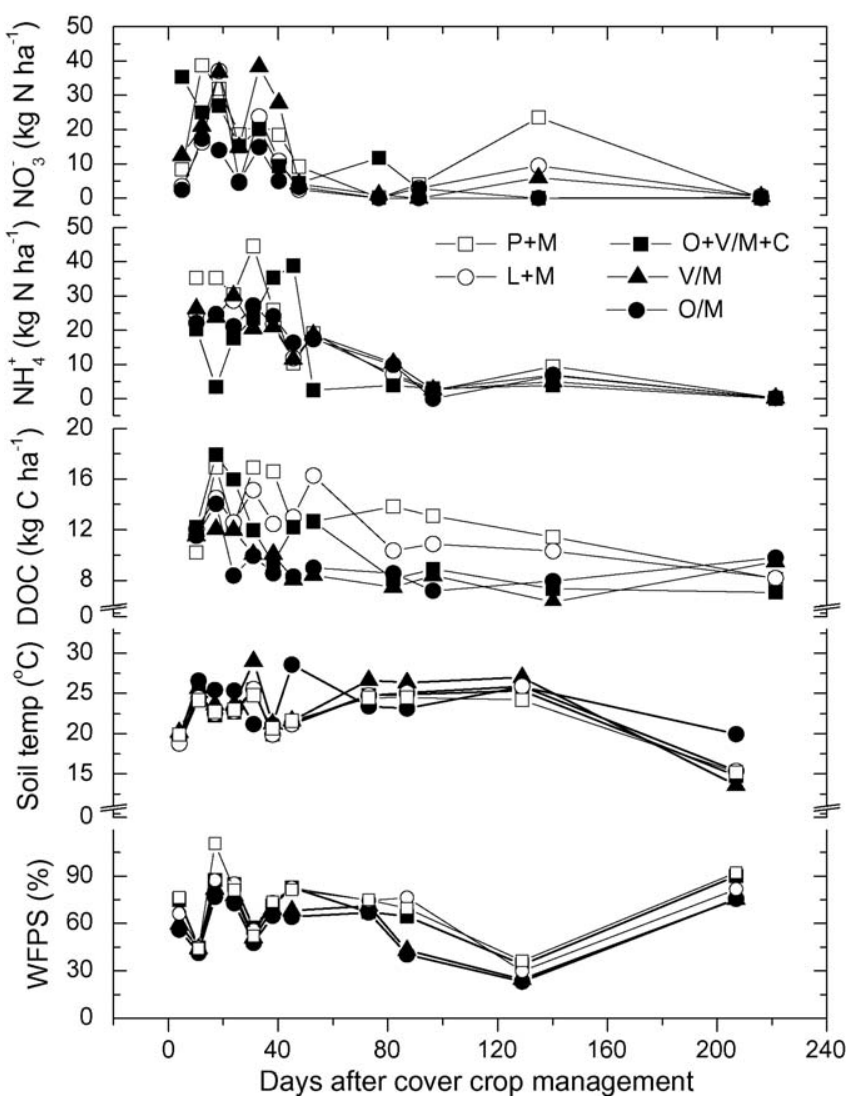

Fig. 3. Temporal variation in mineral $\mathrm{N}\left(\mathrm{NO}_{3}{ }^{-}-\mathrm{N}, \mathrm{NH}_{4}{ }^{+}-\mathrm{N}\right)$, dissolved organic carbon (DOC), and water-filled pore space (WFPS) at $0-0.3 \mathrm{~m}$ layer and soil temperature $\left({ }^{\circ} \mathrm{C}\right)$ at $0-0.05 \mathrm{~m}$ layer of an Acrisol under no-till crop rotations in Southern Brazil. O, oat; V, vetch; C, cowpea; P, pigeon pea; L, lablab; M, maize. Mean values of a composite soil sample from four sub-samples. 


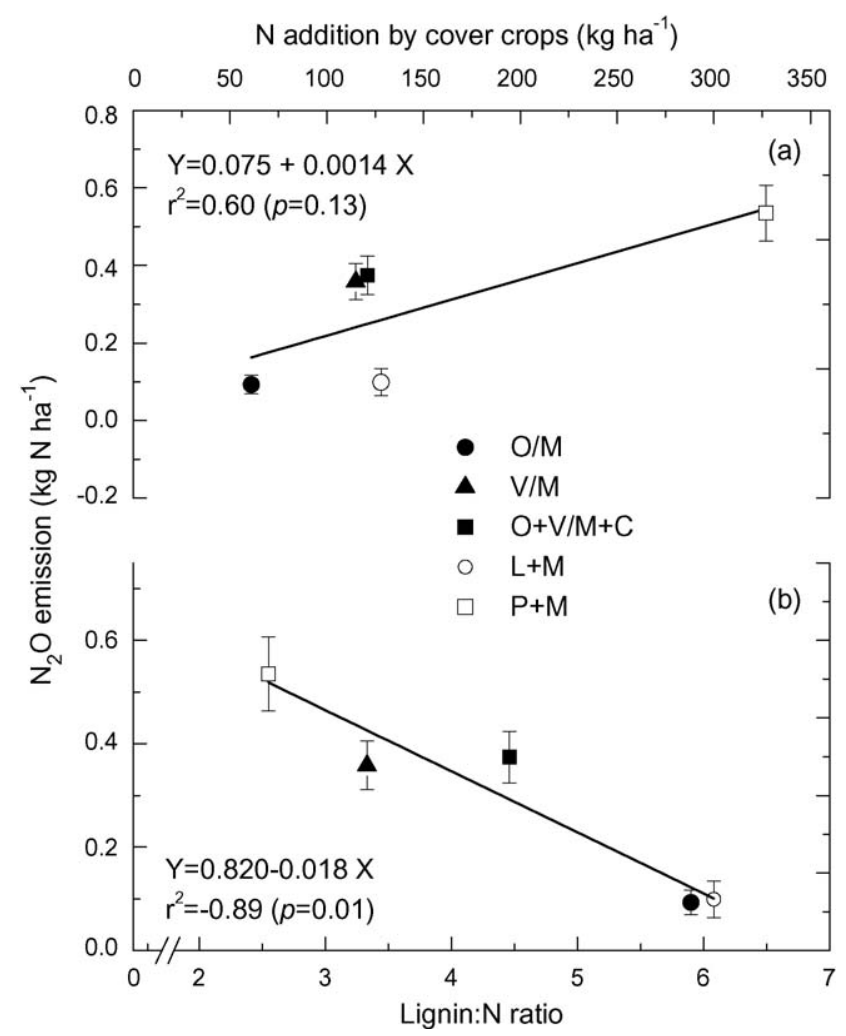

Fig. 4. Relationship between accumulated soil $\mathrm{N}_{2} \mathrm{O}$ emissions in the first 45 days of evaluation (post-management period) and plant biomass attributes [ $\mathrm{N}$ addition (a) and lignin:N ratio (b)] for an Acrisol under no-till crop rotations in Southern Brazil. $\mathrm{O}$, oat; V, vetch; M, maize; C, cowpea; P, pigeon pea; L, lablab. Vertical bars represent the standard deviation $(n=2)$.

cumulative soil $\mathrm{N}_{2} \mathrm{O}$ emission for the post-management period was directly related to the added $\mathrm{N}\left(r^{2}=0.60, p=0.13\right.$; Fig. $\left.4 \mathrm{a}\right)$ and it was negatively related to the lignin: $\mathrm{N}$ ratio of the added cover crop residues $\left(r^{2}=0.89, p=0.01\right.$; Fig. $\left.4 \mathrm{~b}\right)$.

After the post-management period, the mean soil $\mathrm{N}_{2} \mathrm{O}$ emissions of all crop rotations decreased from $27.0 \pm 3.4 \mu \mathrm{g} \mathrm{N} \mathrm{m}^{-2} \mathrm{~h}^{-1}$ (0th to 45th day) to $7.9 \pm 1.5 \mu \mathrm{g} \mathrm{N} \mathrm{m}^{-2} \mathrm{~h}^{-1}$ (46th to 344 th), and the negative fluxes were eventually observed in most crop rotations reaching the greatest uptake rate of $-24.0 \pm 5.4 \mu \mathrm{g} \mathrm{N} \mathrm{m}{ }^{-2} \mathrm{~h}^{-1}$ in the $\mathrm{O} / \mathrm{M}$ system (Fig. 2). In spite of the decrease in magnitude of values, the crop rotations $\mathrm{L}+\mathrm{M}, \mathrm{O}+\mathrm{V} / \mathrm{M}+\mathrm{C}$, and $\mathrm{P}+\mathrm{M}$, which included the tropical legume species, sustained higher emissions than the other crop rotations, similarly to what was observed for the first 45 days period. While the soil $\mathrm{N}_{2} \mathrm{O}$ emissions in the post-management period were related to the $\mathrm{N}$ addition by cover crop biomass, the emissions in the subsequent period were closely related to the total soil $\mathrm{N}$ stocks $\left(r^{2}=0.96, p=0.002\right.$; Fig. 5).

The largest annual soil $\mathrm{N}_{2} \mathrm{O}$ emissions were observed in tropical legume-based crop rotations $(1.116 \pm 0.143,1.316 \pm 0.103$, and $1.323 \pm 0.221 \mathrm{~kg} \mathrm{~N} \mathrm{ha}^{-1}$ for $\mathrm{L}+\mathrm{M}, \mathrm{O}+\mathrm{V} / \mathrm{M}+\mathrm{C}$, and $\mathrm{P}+\mathrm{M}$, respectively; Fig. 6). On the other hand, $30 \%$ less $\mathrm{N}_{2} \mathrm{O}\left(0.805 \pm 0.072 \mathrm{~kg} \mathrm{~N}^{-1}\right)$ was emitted from the soil under the $\mathrm{V} / \mathrm{M}$ than the $\mathrm{L}+\mathrm{M}$ crop rotation, and the $\mathrm{O} / \mathrm{M}$ rotation resulted in a net annual uptake of $-0.074 \pm 0.056 \mathrm{~kg} \mathrm{~N} \mathrm{ha}^{-1}$. Assuming that the total amount of soil $\mathrm{N}_{2} \mathrm{O}$ emitted from the crop rotations in the year was derived from the $\mathrm{N}$ input by crop residues (Table 1 ), it would imply that about $0.39-0.75 \%$ of the added $\mathrm{N}$ were lost as $\mathrm{N}_{2} \mathrm{O}$.

\subsection{Mineral nitrogen, dissolved organic $C$ and water-filled pore space}

Mineral $\mathrm{N}$ and DOC contents in the $0-30 \mathrm{~cm}$ soil layer substantially increased after the management of the cover crop

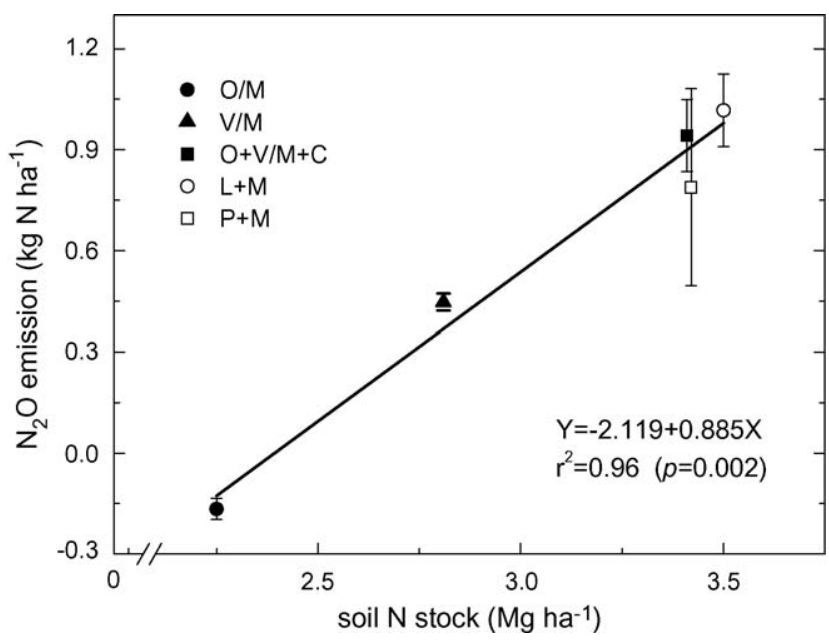

Fig. 5. Relationship between cumulative soil $\mathrm{N}_{2} \mathrm{O}$ emissions from the period after the post-management period (from 45 th to 344 th day period) and the total soil $\mathrm{N}$ stock (0-0.3 m) of an Acrisol under no-till crop rotations in Southern Brazil. O, oat; $\mathrm{V}$, vetch; M, maize; C, cowpea; P, pigeon pea; L, lablab. Vertical bars represent the standard deviation $(n=2)$.

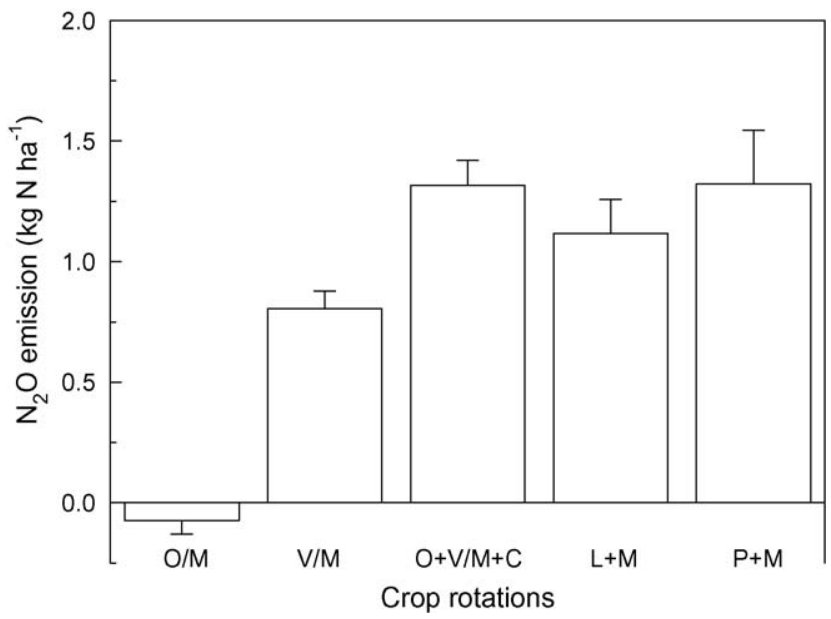

Fig. 6. Annual soil $\mathrm{N}_{2} \mathrm{O}$ emissions from an Acrisol under no-till crop rotations in Southern Brazil. O, oat; V, vetch; M, maize; C, cowpea; P, pigeon pea; L, lablab. Vertical bars represent the standard deviation $(n=2)$.

residue, promoting the highest values in the post-management period (Fig. 3). In the following period, however, their contents were generally low. The sum of $\mathrm{NO}_{3}{ }^{-}$and $\mathrm{NH}_{4}{ }^{+}$contents exceeded $70 \mathrm{~kg} \mathrm{ha}^{-1}$ for the $\mathrm{P}+\mathrm{M}, \mathrm{V} / \mathrm{M}$, and $\mathrm{L}+\mathrm{M}$ in some sampling events (Fig. 3). The highest DOC contents were observed in the soil under $\mathrm{P}+\mathrm{M}$ and $\mathrm{L}+\mathrm{M}$, especially in sampling events immediately after rainfall events (Fig. 3). There was no large difference in the annual mean contents of DOC among the crop rotations. However, the soil under $\mathrm{P}+\mathrm{M}$ and $\mathrm{L}+\mathrm{M}$ systems tended to have higher contents (mean of 13.1 and $12.4 \mathrm{~kg} \mathrm{ha}^{-1}$, respectively) than the $\mathrm{O} / \mathrm{M}$ (mean of $9.4 \mathrm{~kg} \mathrm{ha}^{-1}$ ) and the other legume-based crop rotations (mean of 9.4 and $11.2 \mathrm{~kg} \mathrm{ha}^{-1}$ for $\mathrm{V} / \mathrm{M}$ and $\mathrm{O}+\mathrm{V} / \mathrm{M}+\mathrm{C}$, respectively).

The WFPS in the soil ranged from about $20 \%$ up to $100 \%$, with most values in the $60-80 \%$ range (Fig. 3 ). The crop rotations had negligible effect on the WFPS, which was basically dependent on the rainfall.

\subsection{Multivariate analysis}

The first two ordination axes represented $66 \%$ of the variability in the factors that affect soil $\mathrm{N}_{2} \mathrm{O}$ emissions (Fig. 7). The principal 


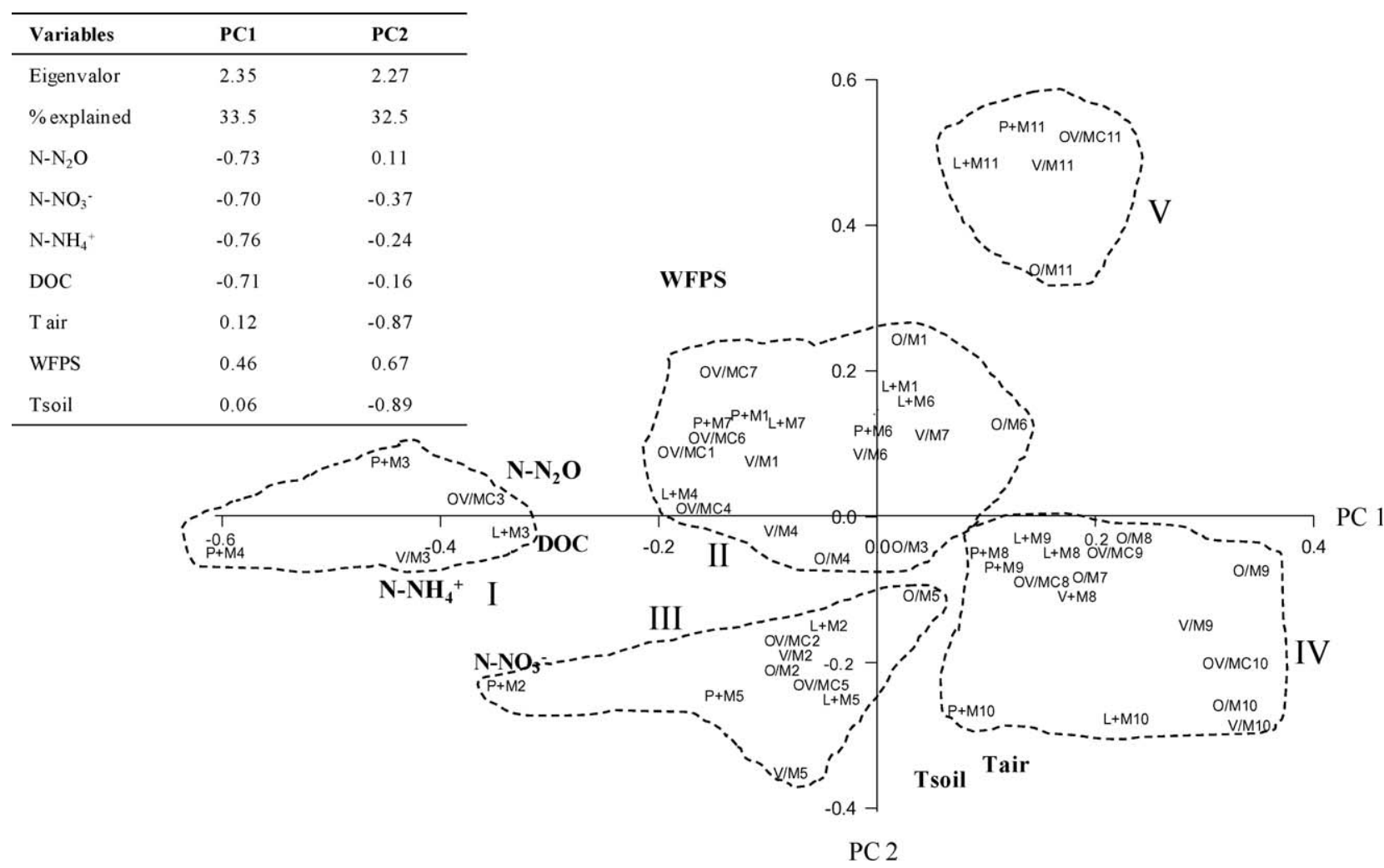



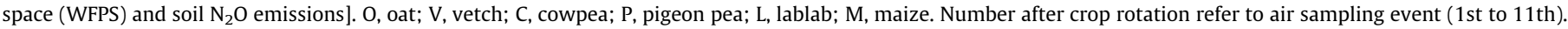

component 1 (PC1) had higher correlation with soil $\mathrm{N}_{2} \mathrm{O}$ emissions and contents of $\mathrm{NO}_{3}{ }^{-}, \mathrm{NH}_{4}{ }^{+}$, and DOC, all of them with relatively similar correlation $(r)$ coefficient $\left(\mathrm{N}_{2} \mathrm{O}:-0.73, \mathrm{NO}_{3}{ }^{-}:-0.70, \mathrm{NH}_{4}{ }^{+}\right.$: -0.76 , DOC: -0.71 ). The principal component 2 (PC2), in turn, represented better the variability of WFPS and soil and air temperature, with the axis having a positive relation with WFPS (0.67) and a negative relation to air and soil temperature $(-0.87$ and -0.89 , respectively). Therefore, PC1 signifies more the variables connected to the effect of crop rotation, while PC2 indicates more the influence of the environmental conditions. The clusters of the crop rotations and corresponding sampling events in the representation of principal component analysis (Fig. 7) allowed assorting the results in five groups. Group I contained the observations with the greatest $\mathrm{N}_{2} \mathrm{O}$ emissions and $\mathrm{NO}_{3}{ }^{-}, \mathrm{NH}_{4}{ }^{+}$ and DOC contents in soil. Groups II and III contained the observations with smaller values of these variables in comparison to group I, and they were distinguished by observations made under higher WFPS conditions (group II) or higher soil temperature conditions (group III). The lowest $\mathrm{N}_{2} \mathrm{O}$ emission observations were grouped in groups IV and V.

\section{Discussion}

\subsection{Effect of legume residues on soil $\mathrm{N}_{2} \mathrm{O}$ fluxes}

The implementation of contrasting crop rotations with no-till management for about two decades clearly affected soil $\mathrm{N}_{2} \mathrm{O}$ emissions in two main ways. First, the effect of crop rotations manifested immediately after the addition of the fresh residues of different quality to the soil by promoting the more intense and short-lived increases in soil $\mathrm{N}_{2} \mathrm{O}$ emissions (Figs. 2 and 4). Second, after the fresh residue effect, the emissions returned to background rates, which were then mainly influenced by the legacy effect of the different crop rotations on long-term soil attributes, especially total N stocks (Fig. 5).

Although the intensity of the soil $\mathrm{N}_{2} \mathrm{O}$ fluxes were a little greater in our study under subtropical climate, similar fast effects of residue addition was observed by Baggs et al. (2006) in a tropical no-tilled soil from Western Kenya. The addition of residues (i.e., Tephrosia and Crotalaria) resulted in short-lived fluxes of $\mathrm{N}_{2} \mathrm{O}$ in comparison with a natural fallow system, and the highest peaks of $\mathrm{N}_{2} \mathrm{O}$ emission occurred on the 20th day after crop residue addition. At the 20th day, the mean soil $\mathrm{N}_{2} \mathrm{O}$ flux from the soil under natural fallow system (control) was about $12 \mu \mathrm{g} \mathrm{N} \mathrm{m}^{-2} \mathrm{~h}^{-1}$, while the residues increased emission up to $110 \mu \mathrm{g} \mathrm{N} \mathrm{m}^{-2} \mathrm{~h}^{-1}$. Other authors have reported similar effects of crop residues on soil $\mathrm{N}_{2} \mathrm{O}$ emissions under field conditions (Rochette et al., 2004; Gregorich et al., 2005).

Legume cover crop-based crop rotations increased soil $\mathrm{N}_{2} \mathrm{O}$ emissions, mainly the tropical legume species, in comparison to the $\mathrm{O} / \mathrm{M}$ system, in which a net annual uptake was observed (Figs. 2 and 6). Increases in soil $\mathrm{N}_{2} \mathrm{O}$ emission after legume residue input to the soil were also documented by other authors (Baggs et al., 2000, 2006; Millar et al., 2004; Millar and Baggs, 2005). Due to the high quality of biomass i.e., low C: $\mathrm{N}$ and lignin: $\mathrm{N}$ ratio (Constantinides and Fownes, 1994; Baggs et al., 2001), the addition of legume residues to the soil stimulates the microbial activity and, thereby, enhances $\mathrm{N}_{2} \mathrm{O}$ emissions for two complementary reasons. First, the fast mineralization of $\mathrm{N}$ from legume residues and the resulting increase in soil mineral $\mathrm{N}\left(\mathrm{NH}_{4}^{+}\right.$and $\left.\mathrm{NO}_{3}{ }^{-}\right)$contents provides substrate for $\mathrm{N}_{2} \mathrm{O}$ production. Second, the increased consumption of available oxygen during legume decomposition increases the occurrence of anaerobic microsites and, therefore, the $\mathrm{N}_{2} \mathrm{O}$ production by denitrification, which is more effective in producing $\mathrm{N}_{2} \mathrm{O}$ than the nitrification process (Khalil and Baggs, 2005). In addition, the deposition and maintenance of crop residues on the soil surface in no-till systems lead to conditions suitable for 
denitrification due to the enhancement of water storage and $C$ supply (Linn and Doran, 1984; Baggs et al. 2003). Both factors can amplify the $\mathrm{N}_{2} \mathrm{O}$ production in legume-cultivated no-till soils (Baggs et al., 2003; Rochette et al., 2004).

Due to all the factors cited above, the greatest soil $\mathrm{N}_{2} \mathrm{O}$ emissions were observed in the first 45 days after the crop residue management (Fig. 2) and they were directly related to the $\mathrm{N}$ input by biomass addition and their quality-mainly expressed by the C:N and lignin:N ratio (Baggs et al., 2001, 2006; Millar and Baggs, 2004; Garcia-Ruiz and Baggs, 2007). The L + M system, however, had only $9 \%$ of the total annual emission in the first 45 days after crop management, which is probably attributed to the fact that the leaves of lablab fall in the winter. Therefore, a substantial proportion of $\mathrm{N}$ from lablab residues had probably mineralized before the post-management period.

It is interesting to note that the presence of black oat residues in addition to vetch in the $\mathrm{O}+\mathrm{V} / \mathrm{M}+\mathrm{C}$ system delayed the increase in soil $\mathrm{N}_{2} \mathrm{O}$ emissions in the post residue management period in comparison to the other legume-based crop rotations. This is likely due to the greater $\mathrm{C}: \mathrm{N}$ and lignin: $\mathrm{N}$ ratios (Table 2 ) of the oat residues, promoting greater $\mathrm{N}$ immobilization during residue decomposition (Garcia-Ruiz and Baggs, 2007). The delay in $\mathrm{N}$ mineralization would help to keep the mineral $\mathrm{N}$ levels low in the soil, potentially enhancing the synchronism between $\mathrm{N}$ mineralization and plant uptake (Amado et al., 1998; Baggs et al., 2001) and, thereby, decreasing soil $\mathrm{N}_{2} \mathrm{O}$ emissions. Moreover, the use of vetch plus oat as mixed cover crops is a viable option for reducing the chemical $\mathrm{N}$ fertilizer requirements by the cash crop because of the biological $\mathrm{N}$ fixation by the vetch (Amado et al., 1998).

Soil $\mathrm{N}_{2} \mathrm{O}$ uptake was eventually observed in almost all crop rotations after the first 45 days of evaluation, and the $\mathrm{O} / \mathrm{M}$ system had the highest annual net uptake of $-0.074 \pm 0.056 \mathrm{~kg} \mathrm{~N} \mathrm{ha}^{-1}$ year $^{-1}$. Soil $\mathrm{N}_{2} \mathrm{O}$ uptake has been reported under different soil and climate conditions at rates up to $-484 \mu \mathrm{g} \mathrm{N} \mathrm{m}^{-2} \mathrm{~h}^{-1}$ (Chapuis-Lardy et al., 2007). The $\mathrm{N}_{2} \mathrm{O}$ uptake in arable soils has been attributed to the conversion of $\mathrm{N}_{2} \mathrm{O}$ to $\mathrm{N}_{2}$ in the denitrification process, when $\mathrm{NO}_{3}{ }^{-}$ concentration is low and WFPS is high (Blackmer and Bremner, 1978; Chapuis-Lardy et al., 2007). However, additional research is required for a more complete understanding, especially considering the potential of GHG mitigation this $\mathrm{N}_{2} \mathrm{O}$ uptake can entail in agricultural soils.

The larger total soil $\mathrm{N}$ stocks under the tropical legume-based rotations than in the $\mathrm{V} / \mathrm{M}$ and $\mathrm{O} / \mathrm{M}$ systems led to greater soil $\mathrm{N}_{2} \mathrm{O}$ fluxes in the period following the post-management period. The greater input to the soil of biomass and $\mathrm{N}$ through biological $\mathrm{N}$ fixation promoted a gradual raise in total $\mathrm{N}$ stocks in the soils cultivated with legume species (Amado et al., 1998; Diekow et al., 2005). The greater $\mathrm{N}$ stocks enhance $\mathrm{N}$ mineralization and consequently induce the potential of soil $\mathrm{N}_{2} \mathrm{O}$ emissions. Under the conditions of this study, the $\mathrm{N}$ input by crop residues was, therefore, more important in controlling soil $\mathrm{N}_{2} \mathrm{O}$ emissions in the short-term (i.e., the first 45 days after cover crop residue management), while the total soil $\mathrm{N}$ stock was more important in the subsequent period. These results illustrate that the longterm historical soil use and management influence soil $\mathrm{N}_{2} \mathrm{O}$ emissions, and not only the short-term effects of treatments, is of importance in regulating $\mathrm{N}_{2} \mathrm{O}$ emissions.

The annual soil $\mathrm{N}_{2} \mathrm{O}$ emissions were a relatively low percentage of the total $\mathrm{N}$ added to the soil $(0.39-0.75 \%)$ when compared to the mean losses of $1.25 \pm 1.0 \%$ globally ascribed for $\mathrm{N}$ inputs to arable soils (IPCC, 2006). The IPCC emission factors have been criticized by many researchers, especially in relation to concerns about their generalized adoption in GHG inventories (Rochette et al., 2004; Gregorich et al., 2005). In a recent study carried out in Southern Brazil, Jantalia et al. (2008) verified the same tendency of overestimation of $\mathrm{N}_{2} \mathrm{O}$ emission by using IPCC emission factors. The use of IPCC factors resulted in estimates of $23-250 \%$ greater than field $\mathrm{N}_{2} \mathrm{O}$ measurements (Jantalia et al., 2008).

The maximum annual emission in the present work under subtropical climate was about $1.323 \pm 0.221 \mathrm{~kg} \mathrm{~N} \mathrm{ha}^{-1}$ year $^{-1}$, which falls within the range of $0.16-3.70 \mathrm{~kg} \mathrm{~N} \mathrm{ha}^{-1}$ year $^{-1}$ reported by Gregorich et al. (2005) for Canadian arable soils, and is proportionally similar to the cumulative emissions (99 days) for several agroforestry residues in Kenya; they ranged from about 0.10 to $0.60 \mathrm{~kg} \mathrm{~N}_{2} \mathrm{O}-\mathrm{N} \mathrm{ha}^{-1}$ (Baggs et al., 2006). However, our results are less than the mean annual emission rates of $2.70 \mathrm{~kg} \mathrm{~N} \mathrm{ha}^{-1} \mathrm{year}^{-1}$ for European arable soils (Melillo et al., 2001).

\subsection{Variables driving soil $\mathrm{N}_{2} \mathrm{O}$ emissions}

In addition to the crop residue effect, soil $\mathrm{N}_{2} \mathrm{O}$ emissions were impacted by soil physical conditions (i.e., WFPS), which were likely influencing oxygen availability (Beauchamp, 1997; Neill et al., 2005). Similar to the studies of Marinho et al. (2004) and Du et al. (2006) the greatest daily soil $\mathrm{N}_{2} \mathrm{O}$ emissions were observed immediately after rainfall events, mainly at the 18th and 25th day after crop residues management, when WFPS was indeed high and consequently oxygen availability in the soil must have been low. Taking into account that the mineral $\mathrm{N}$ content, especially $\mathrm{NO}_{3}$ content, in the post-management period was not limiting, the increases in WFPS probably generated anaerobic sites where denitrification of $\mathrm{NO}_{3}{ }^{-}$was intensified (Dobbie and Smith, 2003; Neill et al., 2005). In addition, greater $\mathrm{NO}_{3}{ }^{-}$concentrations in soil may have inhibited the conversion of $\mathrm{N}_{2} \mathrm{O}$ to $\mathrm{N}_{2}$ because of the preference for $\mathrm{NO}_{3}{ }^{-}$instead of $\mathrm{N}_{2} \mathrm{O}$ as final electron acceptor (Blackmer and Bremner, 1978; Chapuis-Lardy et al., 2007). It has been suggested that $\geq 10 \mathrm{mg} \mathrm{NO}-\mathrm{N} \mathrm{kg}^{-1}$ soil is the threshold value for such inhibition. However, we observed a maximum mean concentration of $8 \mathrm{mg} \mathrm{NO}_{3}{ }^{-}-\mathrm{N} \mathrm{kg}^{-1}$ for the $0-0.3 \mathrm{~m}$ (approximately $38 \mathrm{~kg} \mathrm{ha}^{-1}$ in the $0-0.3 \mathrm{~cm}$ layer, Fig. 3 ). Probably, the greater depth of soil sampling diluted the mean $\mathrm{NO}_{3}{ }^{-}$content, as $\mathrm{N}$ mineralization from crop residues in no-till mostly occurs in the surface soil layers. In the same experiment as in the present study, Dieckow et al. (data not published) found frequently $\mathrm{NO}_{3}{ }^{-}-\mathrm{N}$ contents higher than $15 \mathrm{mg} \mathrm{N} \mathrm{kg}^{-1}$ in the $0-0.05 \mathrm{~m}$ soil layer under legume cover crops-based rotations. Therefore, $\mathrm{NO}_{3}{ }^{-}-\mathrm{N}$ concentrations were probably high enough to inhibit the reduction of $\mathrm{N}_{2} \mathrm{O}$ to $\mathrm{N}_{2}$ in certain parts of the $0-0.3 \mathrm{~m}$ soil layer.

The results of the multivariate analysis pointed to an interaction among the driving factors controlling soil $\mathrm{N}_{2} \mathrm{O}$ emissions in the present study. The most important factors were mineral $\mathrm{N}\left(\mathrm{NH}_{4}^{+}, \mathrm{NO}_{3}{ }^{-}\right)$and DOC contents, and they interacted with soil WFPS, as observed in the grouping interpretation (Fig. 7). Group I contained the observations with greatest $\mathrm{N}_{2} \mathrm{O}$ emissions (mean of $102.5 \mu \mathrm{g} \mathrm{N}-\mathrm{N}_{2} \mathrm{O} \mathrm{m}^{-2} \mathrm{~h}^{-1}$ ), was composed mainly by legume-based cropping systems, and the emissions were directly related to the largest soil mineral $\mathrm{N}$ and DOC contents, but no distinctive importance was observed between these factors as correlation coefficients of these factors and PC1 axis were very similar. On the other hand, the air temperature and WFPS seemed to have secondary importance, demonstrating that the soil management effect was more important for determining the greatest $\mathrm{N}_{2} \mathrm{O}$ emission. This affirmation is supported by the fact that $\mathrm{N}_{2} \mathrm{O}$ emission was better related to PC1 axis, similarly to the $\mathrm{NH}_{4}{ }^{+}, \mathrm{NO}_{3}{ }^{-}$, and DOC contents, while air temperature and WFPS were better related to $\mathrm{PC}$.

Observations classified in groups II and III had lower soil $\mathrm{N}_{2} \mathrm{O}$ emissions (mean 27.1 and $7.1 \mu \mathrm{g} \mathrm{N} \mathrm{m}^{-2} \mathrm{~h}^{-1}$, respectively) than those from group I, which was related to the decrease in mineral $\mathrm{N}$ and DOC and or in WFPS. However, between groups II and III, the management-controlled parameters (mineral $\mathrm{N}$ and DOC) were similar (Fig. 3) and therefore the greater mean soil $\mathrm{N}_{2} \mathrm{O}$ emission 
from group II than from group III was due to greater soil WFPS (Fig. 3), reducing the oxygen availability and enhancing denitrification (Beauchamp, 1997). Several authors have indicated the predominance of denitrification as the source for $\mathrm{N}_{2} \mathrm{O}$ production in soils when WFPS values are larger than 70\% (Bateman and Baggs, 2005; Khalil and Baggs, 2005; Ciarlo et al., 2007). Similar to the study of Marinho et al. (2004), the greatest daily fluxes were observed immediately after rainfall events (Fig. 2), mainly at the 18th and 25th day after crop residue management, when WFPS was high (Fig. 3). Assuming that the mineral $\mathrm{N}$ content in the postmanagement period was not limiting, especially $\mathrm{NO}_{3}{ }^{-}$, the increases in WFPS generated anaerobic sites where denitrification was intensified (Dobbie and Smith, 2003). In addition, greater $\mathrm{NO}_{3}{ }^{-}$concentrations in soil may have inhibited the conversion of $\mathrm{N}_{2} \mathrm{O}$ to $\mathrm{N}_{2}$, as previously discussed.

Group IV consists of flux observations ranging from very low $\mathrm{N}_{2} \mathrm{O}$ emissions to even uptake of $\mathrm{N}_{2} \mathrm{O}$, with a mean of $-1.33 \mu \mathrm{g} \mathrm{N} \mathrm{m}^{-2} \mathrm{~h}^{-1}$. In this group, both the low DOC and $\mathrm{N}$ availability and the low WFPS led to low $\mathrm{N}_{2} \mathrm{O}$ emissions and even an uptake of $\mathrm{N}_{2} \mathrm{O}$. Group $\mathrm{V}$, however, had similar DOC and $\mathrm{N}$ availability as in group IV, but the WFPS was greater in group V than in group IV, leading to the greater emissions (mean of $11.5 \mu \mathrm{g} \mathrm{N} \mathrm{m}^{-2} \mathrm{~h}^{-1}$ ). However, the flux rates were still modest when compared to those observed in group I, probably because of the limited available of $\mathrm{C}$ and mineral $\mathrm{N}$.

In summary, among all the variables, those related to differences in management practices affected more soil $\mathrm{N}_{2} \mathrm{O}$ fluxes. The environmental variables were important only when $\mathrm{C}$ and $\mathrm{N}$ availability were not limiting, and even when they were not limiting, soil $\mathrm{N}_{2} \mathrm{O}$ emissions were more responsive to increases in $\mathrm{N}$ availability and DOC contents than to increases in WFPS. Similarly, by using a multivariate approach, Lee et al. (2006) have reported that the labile $\mathrm{C}$ and $\mathrm{N}$ availability were the main driving variables controlling $\mathrm{N}_{2} \mathrm{O}$ fluxes from no-tillage and standard tillage soils.

In this context, controlling the synchronization between $\mathrm{N}$ mineralization/availability and its uptake by plants seems to be the best option to mitigate $\mathrm{N}_{2} \mathrm{O}$ emissions from legume residueamended soils. It can be inferred, therefore, that management practices aiming at decreasing soil $\mathrm{N}_{2} \mathrm{O}$ emissions should maximize plant growth and avoid fallow periods. Even though cover crops legumes contribute considerably to the soil $\mathrm{N}_{2} \mathrm{O}$ emissions, a global analysis of the environmental services of legume cover crops in agricultural systems should be performed for evaluating their effect on net global warming potential by considering also the increased carbon sequestration in soil, the fluxes of methane and the reduction of carbon costs from reduced $\mathrm{N}$ fertilizer use (MeyerAurich et al., 2006), in addition to their agronomic benefits and positive effects on soil quality (Reeves, 1997; Six et al., 2004).

\section{Conclusions}

Legume cover crops increase soil $\mathrm{N}_{2} \mathrm{O}$ emissions to the atmosphere. Greater soil $\mathrm{N}_{2} \mathrm{O}$ emissions are observed in the short period ( 45 days in this study) after cover crop management and are directly related to the quantity of $\mathrm{N}$ and inversely related to the quality (lignin: $\mathrm{N}$ ratio) of the cover crop biomass. After this initial short period, $\mathrm{N}$ stocks drive soil $\mathrm{N}_{2} \mathrm{O}$ emission in long-term no-till crop rotations. These effects of soil conditions and cover crops on $\mathrm{N}_{2} \mathrm{O}$ emissions are mainly related to the $\mathrm{N}$ availability and labile $\mathrm{C}$ supply. Management-controlled soil variables such as mineral $\mathrm{N}$ $\left(\mathrm{NO}_{3}{ }^{-}\right.$and $\left.\mathrm{NH}_{4}{ }^{+}\right)$and DOC contents are more related to soil $\mathrm{N}_{2} \mathrm{O}$ emissions than environmental-related variables as water-filled pore space and air and soil temperature. Thus, managing the synchronism between $\mathrm{N}$ mineralization/availability and its uptake by plants is the most pertinent to control $\mathrm{N}_{2} \mathrm{O}$ emissions from legume residue-amended soils.

\section{References}

Amado, T.J.C., Mielniczuk, J., Fernandes, S.B., 1998. Nitrogen availability as affected by ten years of cover crops and tillage systems in Southern Brazil. J. Soil Water Conserv. 53, 268-272.

Aulakh, M.S., Khera, T.S., Doran, J.W., Bronson, K.F., 2001. Denitrification, $\mathrm{N}_{2} \mathrm{O}$ and $\mathrm{CO}_{2}$ fluxes in rice-wheat cropping system as affected by crop residues, fertilizer $\mathrm{N}$ and legume green manure. Biol. Fertil. Soils 34, 375-389.

Baggs, E.M., Chebii, J., Ndufa, J.K., 2006. A short-term investigation of trace gas emissions following tillage and no-tillage of agroforestry residues in western Kenya. Soil Till. Res. 90, 69-76.

Baggs, E.M., Millar, N., Ndufa, J.K., Cadisch, G., 2001. Effect of residue quality on $\mathrm{N}_{2} \mathrm{O}$ Emissions from tropical soils. In: Rees, R.M., Ball, B.C., Campbell, C.D., Watson, C.A. (Eds.), Sustainable Management of Soil Organic Matter. CAB International, Oxford, pp. 120-125.

Baggs, E.M., Rees, R.M., Smith, K.A., Vinten, A.J.A., 2000. Nitrous oxide emission from soils after incorporating crop residues. Soil Use Manage. 16, 82-87.

Baggs, E.M., Stevenson, M., Pihlatie, M., Regar, A., Cook, H., Cadisch, G., 2003. Nitrous oxide emissions following application of residues and fertilizer under zero and conventional tillage. Plant Soil 254, 361-370.

Ball, B.C., Scott, A., Parker, J.P., 1999. Field $\mathrm{N}_{2} \mathrm{O}, \mathrm{CO}_{2}$ and $\mathrm{CH}_{4}$ fluxes in relation to tillage, compaction and soil quality in Scotland. Soil Till. Res. 53, 29-39.

Bateman, E.J., Baggs, E.M., 2005. Contributions of nitrification and denitrification to $\mathrm{N}_{2} \mathrm{O}$ emissions from soils at different water-filled pore space. Biol. Fertil. Soils 41, 379-388.

Beauchamp, E.G., 1997. Nitrous oxide emission from agricultural soils. Can. J. Soil Sci. 77, 113-123.

Blackmer, A.M., Bremner, J.M., 1978. Inhibitory effect of nitrate on reduction of $\mathrm{N}_{2} \mathrm{O}$ to $\mathrm{N}_{2}$ by soil-microorganisms. Soil Biol. Biochem. 10, 187-191.

Bremner, J.M., 1960. Determination of nitrogen in soil by the Kjeldahl method. J. Agric. Sci. 55, 11-33.

Carmo, J.B., Piccolo, M.C., Andrade, C.A., Cerri, C.E.P., Feigl, B.J., Neto, E.S., Cerri, C.C., 2007. Short-term changes in nitrogen availability, gas fluxes $\left(\mathrm{CO}_{2}, \mathrm{NO}, \mathrm{N}_{2} \mathrm{O}\right)$ and microbial biomass after tillage during pasture re-establishment in Rondônia, Brazil. Soil Till. Res 96, 250-259.

Chantigny, M.H., 2003. Dissolved and water-extractable organic matter in soils: a review on the influence of land use and management practices. Geoderma 113 357-380.

Chapuis-Lardy, L., Wrage, N., Metay, A., Chotte, J.L., Bernoux, M., 2007. Soils, a sink for $\mathrm{N}_{2} \mathrm{O}$ ? A review. Global Change Biol. 13, 1-17.

Ciarlo, E., Conti, M., Bartoloni, N., Rubio, G., 2007. The effect of moisture on nitrous oxide emissions from soil and the $\mathrm{N}_{2} \mathrm{O} /\left(\mathrm{N}_{2} \mathrm{O}+\mathrm{N}_{2}\right)$ ratio under laboratory conditions. Biol. Fertil. Soils 43, 675-681.

Constantinides, M., Fownes, J.H., 1994. Nitrogen mineralization from leaves and litter of tropical plants-relationship to nitrogen, lignin and soluble polyphenol concentrations. Soil Biol. Biochem. 26, 49-55.

Diekow, J., Mielniczuk, J., Knicker, H., Bayer, C., Dick, D.P., Kogel-Knabner, I., 2005. Soil $\mathrm{C}$ and $\mathrm{N}$ stocks as affected by cropping systems and nitrogen fertilization in a Southern Brazil Acrisol managed under no-tillage for 17 years. Soil Till. Res. 81, 87-95.

Dobbie, K.E., Smith, K.A., 2003. Nitrous oxide emission factors for agricultural soils in Great Britain: the impact of soil water-filled pore space and other controlling variables. Global Change Biol. 9, 204-218.

Du, R., Lu, D.R., Wang, G.C., 2006. Diurnal, seasonal and inter-annual variation of $\mathrm{N}_{2} \mathrm{O}$ fluxes from native semi-arid grassland soils of inner Mongolia. Soil Biol. Biochem. 38, 3471-3482.

Ellert, B.H., Bettany, J.R., 1995. Calculation of organic matter and nutrients stored in soils under contrasting management regimes. Can. J. Soil Sci. 75, 529-538.

EMBRAPA (Empresa Brasileira de Pesquisa Agropecuária), 2006. Primeiro inventário brasileiro de emissões antrópicas de gases de efeito estufa: emissões de óxido nitroso proveniente de solos agrícolas. Ministério da Ciência e Tecnologia, Brasília, Brazil.

Garcia-Ruiz, R., Baggs, E.M., 2007. $\mathrm{N}_{2} \mathrm{O}$ emission from soil following combined application of fertiliser-N and ground weed residues. Plant Soil 299, 263-274.

Giacomini, S.J., Jantalia, C.P., Aita, C., Urquiaga, S., Alves, B.J.R., 2006. Emissão de óxido nitroso com a aplicação de dejetos líquidos de suínos em solo sob plantio direto. Pesq. Agrop. Bras. 41, 1653-1661.

Gregorich, E.G., Rochette, P., van den Bygaart, A.J., Angers, D.A., 2005. Greenhouse gas contributions of agricultural soils and potential mitigation practices in Eastern Canada. Soil Till. Res. 83, 53-72.

Huang, Y., Zou, J.W., Zheng, X.H., Wang, Y.S., Xu, X.K., 2004. Nitrous oxide emissions as influenced by amendment of plant residues with different C: $\mathrm{N}$ ratios. Soil Biol. Biochem. 36, 973-981.

IPCC (Intergovernmental Panel on Climate Change), 2006. In: Eggleston, H.S., Buendia, L., Miwa, K., Ngara, T., Tanabe, K. (Eds.), Guidelines for National Greenhouse Gas Inventories, vol. 4, Agriculture, Forestry and Other Land Use. National Greenhouse Gas Inventories Programme.

Isermann, K., 1994. Agricultures share in the emission of trace gases affecting the climate and some cause-oriented proposals for sufficiently reducing this share. Environ. Pollut. 83, 95-111.

Jantalia, C.P., Santos, H.P., Urquiaga, S., Boddey, R.M., Alves, B.J.R., 2008. Fluxes of nitrous oxide from soil under different crop rotations and tillage systems in the South of Brazil. Nutr. Cycling Agroecosyst. 82, 161-173.

Kaiser, E.A., Kohrs, K., Kucke, M., Schnug, E., Heinemeyer, O., Munch, J.C., 1998 Nitrous oxide release from arable soil: Importance of $\mathrm{N}$-fertilization, crops and temporal variation. Soil Biol. Biochem. 30, 1553-1563. 
Khalil, M.I., Baggs, E.M., 2005. $\mathrm{CH}_{4}$ oxidation and $\mathrm{N}_{2} \mathrm{O}$ emissions at varied soil waterfilled pore spaces and headspace $\mathrm{CH}_{4}$ concentrations. Soil Biol. Biochem. 37 , 1785-1794.

Lee, J., Six, J., King, A.P., van Kessel, C.V., Rolston, D.E., 2006. Tillage and field scale controls on greenhouse gas emissions. J. Environ. Qual. 35, 714-725.

Linn, D.M., Doran, J.W., 1984. Effect of water-filled pore-space on carbon-dioxide and nitrous-oxide production in tilled and no tilled soils. Soil Sci. Soc. Am. J. 48, 1267-1272.

Marinho, E.V.A., DeLaune, R.D., Lindau, C.W., 2004. Nitrous oxide flux from soybeans grown on Mississippi alluvial soil. Commun. Soil Sci. Plant Anal. 35, 1-8.

Melillo, J.M., Steudler, P.A., Feigl, B.J., Neill, C., Garcia, D., Piccolo, M.C., Cerri, C.C., Tian, H., 2001. Nitrous oxide emissions from forests and pastures of various ages in the Brazilian Amazon. J. Geophys. Res. 106, 34179-34188.

Meyer-Aurich, A., Weersink, A., Janovicek, K., Deen, B., 2006. Cost efficient rotation and tillage options to sequester carbon and mitigate GHG emissions from agriculture in Eastern Canada. Agric. Ecosyst. Environ. 117, 119-127.

Mielniczuk, J., Bayer, C., Vezzani, F.M., Lovato, T., Fernandes, F.F., Debarba, L., 2003. Manejo de solo e culturas e sua relação com os estoques de carbono e nitrogênio do solo. Tópicos em Ci. Solo 3, 209-248.

Millar, N., Baggs, E.M., 2004. Chemical composition, or quality, of agroforestry residues influences $\mathrm{N}_{2} \mathrm{O}$ emissions after their addition to soil. Soil Biol. Biochem. 36, 935-943.

Millar, N., Baggs, E.M., 2005. Relationships between $\mathrm{N}_{2} \mathrm{O}$ emissions and watersoluble $\mathrm{C}$ and $\mathrm{N}$ contents of agroforestry residues after their addition to soil. Soil Biol. Biochem. 37, 605-608.

Millar, N., Ndufa, J.K., Cadisch, G., Baggs, E.M., 2004. Nitrous oxide emissions following incorporation of improved-fallow residues in the humid tropics. Global Biogeochem. Cycles 18, 1032.
Mosier, A.R., Delgado, J.A., Keller, M., 1998. Methane and nitrous oxide fluxes in an acid Oxisol in western Puerto Rico: effects of tillage, liming and fertilization. Soil Biol. Biochem. 30, 2087-2098.

Neill, C., Steudler, P.A., Garcia-Montiel, D.C., Melillo, J.M., Feigl, B.J., Piccolo, M.C., Cerri, C.C., 2005. Rates and controls of nitrous oxide and nitric oxide emissions following conversion of forest to pasture in Rondonia. Nutr. Cycling Agroecosyst. 71, 1-15.

Pavei, M.A., 2005. Decomposicão de residuos culturais e emissão de gases do efeito estufa em sistemas de manejo do solo em Ponta Grossa (PR). Escola Superior Luiz de Queiroz, Piracicaba, p. 114

Pillar, V.D., 1997. Multivariate exploratory analysis and randomization testing with MULTIV. Coenoses 12, 145-148.

Reeves, D.W., 1997. The role of soil organic matter in maintaining soil quality in continuous cropping systems. Soil Till. Res. 43, 131-167.

Rochette, P., Angers, D.A., Belanger, G., Chantigny, M.H., Prevost, D., Levesque, G., 2004. Emissions of $\mathrm{N}_{2} \mathrm{O}$ from alfalfa and soybean crops in eastern Canada. Soil Sci. Soc. Am. J. 68, 93-506.

Six, J., Ogle, S.M., Breidt, F.J., Conant, R.T., Mosier, A.R., Paustian, K., 2004. The potential to mitigate global warming with no-tillage management is only realized when practiced in long term. Global Change Biol. 10, 155-160.

van Soest, P.J., Wine, R.H., 1968. Determination of lignin and cellulose in aciddetergent fiber with permanganate. J. Assoc. Anal. Chem. 51, 780-785.

Vieira, F.C.B., Bayer, C., Mielniczuk, J., Zanatta, J.A., Bissani, C.A., 2008. Long-term acidification of a Brazilian Acrisol as affected by no-till cropping systems and nitrogen fertilizer. Aust. J. Soil Res. 46, 17-26.

Zanatta, J.A., Bayer, C., Dieckow, J., Vieira, F.C.B., Mielniczuk, J., 2007. Soil organic carbon accumulation and carbon costs related to tillage, cropping systems and nitrogen fertilization in a subtropical Acrisol. Soil Till. Res. 94, 510-519. 